\title{
The influence of dietary molybdenum on the xanthine oxidase activity of the milk of ruminants
}

\author{
BY L. I. HART,* E. C. OWEN AND R. PROUDFOOT $†$ \\ Hannah Dairy Research Institute, Ayr, Scotland \\ (Received 9 November I966-Accepted 27 February 1967)
}

\begin{abstract}
1. The oral administration of sodium molybdate caused a rapid rise of molybdenum in the milk of cows and goats fed on a low-molybdenum diet, but did not affect the xanthine oxidase activities of the milk of either species.

2. In the milks of cows not dosed with sodium molybdate, the regression of the xanthine oxidase activity $(y)$ on the molybdenum content $(x)$ was found to be $y=170.7 x+43.86 \quad(r=+0.9386 ; P<0.001)$

suggesting that all the molybdenum of such milk is bound to enzymically active xanthine oxidase.

3. The molybdenum contents of the milk of goats not dosed with sodium molybdate varied from animal to animal and the xanthine oxidase activities were much lower than those of cow's milk. There was no correlation between xanthine oxidase activity and the molybdenum content of the milks of the goats.

4. These results are discussed in relation to previous work of the authors and others.
\end{abstract}

The occurrence of xanthine oxidase activity in cow's and goat's milks, first observed by Morgan, Stewart \& Hopkins (1922) and the presence of molybdenum in cow's milk (ter Meulen, I932) and goat's milk (Teresi, Elvehjem \& Hart, I942) remained unrelated observations until Richert \& Westerfeld (1953) and De Renzo, Kaleita, Heytler, Oleson, Hutchings \& Williams (I953) showed that Mo was the dietary constituent which had till then been called the 'xanthine oxidase factor'. This factor was postulated to explain why some diets of equal protein content were better than others in enabling rats to maintain the level of xanthine oxidase in the liver. Totter, Burnett, Monroe, Whitney \& Comar (1953) and Green \& Beinert (1953) showed that Mo is a constituent of purified xanthine oxidase (xanthine: oxygen oxidoreductase, EC 1.2.3.2) isolated from cow's milk. The purified enzyme isolated from this source is a reddish-brown protein with a molecular weight of 275000 (Andrews, Bray, Edwards \& Shooter, 1964). Highly purified preparations have been found to contain, per molecule of protein, eight atoms of iron, two molecules of flavine-adenine dinucleotide (FAD), and variable amounts, usually $\mathbf{I}^{\prime} 3^{-\mathrm{I}} \cdot 5$ atoms, of Mo (Avis, Bergel \& Bray, I956; Bray, Pettersson \& Ehrenberg, 196I). The specific activity (expressed as the ratio of activity to extinction at $450 \mathrm{~nm}$ ) is also variable, but this variation is not directly correlated with the variation in Mo content (Avis et al. 1956; Bray et al. 1961). The Mo is firmly bound to the protein, and cannot be removed without destroying the purine oxidase activity (Bergel \& Bray, 1958).

Kiermeier \& Capellari (1958) determined the xanthine oxidase activities and Mo

* Present address: The Chester Beatty Research Institute, Institute of Cancer Research: Royal Cancer Hospital, Fulham Road, London, $\mathrm{SW}_{3}$.

+ Present address: Physiological Laboratory, Cambridge. 
contents of cow's milk from various sources, and observed that the xanthine oxidase activity of cow's milk was proportional to its Mo content. Both the activity and the Mo content were dependent on the level of Mo naturally present in the diet. Kiermeier \& Capellari (1958) found also that oral administration of ammonium molybdate to cows caused an increase in the Mo content of their milk but did not change its xanthine oxidase activity.

The present paper describes investigations of the relationship between the Mo intake of cows and goats maintained on a low-Mo diet and the xanthine oxidase activities and Mo contents of their milks.

\section{EXPERIMENTAL}

Determination of xanthine oxidase activity of cow's milk. Xanthine oxidase activity was determined by measuring the effect on the rate of oxygen uptake by xanthine in the presence of air, in a Warburg apparatus. Before the determination of activity, milk was warmed to $37^{\circ}$ and shaken for $60-75 \mathrm{~min}$ in a reciprocating shaker to release bound xanthine oxidase activity (Worden, 1943). For the determination of activity in cow's milk the reaction mixture consisted of $0.2-0.5 \mathrm{ml}$ shaken milk $+2.0 \mathrm{ml}$ $0.25 \mathrm{M}$-glycine/0.25 M-sodium phosphate buffer, $\mathrm{pH}_{9.2}$ at $20^{\circ}\left(\mathrm{pH} 8.8\right.$ at $\left.37^{\circ}\right)$, $+0.2 \mathrm{ml} 0.02 \mathrm{M}$-xanthine $(4 \mu$ moles $)+\mathrm{I} \mathrm{mg}$ crystalline catalase $+100 \mu$ moles ethanol in a final volume of $3.4 \mathrm{ml}$ at a reaction temperature of $37^{\circ}$. The gas phase was air. The centre well of the Warburg flask contained $0.2 \mathrm{ml} 20 \%(\mathrm{w} / \mathrm{v})$ potassium hydroxide together with a piece of filter paper. After temperature equilibration the reaction was started by adding the xanthine from the side-arm and was allowed to continue for at least $30 \mathrm{~min}$. Pressure readings were taken every $3 \mathrm{~min}$ after the first $6 \mathrm{~min}$ of reaction. Under these conditions the oxidation of xanthine proceeds as follows (Keilin \& Hartree, 1945):<smiles></smiles><smiles>CC(=O)OCCCCO</smiles>

$$
\mathrm{CH}_{3} \mathrm{CHO} \stackrel{\mathrm{KOH}}{\longrightarrow} \text { inert condensation product }
$$

The rate of oxygen uptake remained constant until the xanthine was completely oxidized. It was found, in agreement with Keilin \& Hartree (1945), that exactly I mole of oxygen was taken up per mole of xanthine oxidized. The rate of oxygen uptake was determined graphically and was expressed as $\mu \mathrm{l} \mathrm{O}_{2} / \mathrm{h}$ per $\mathrm{ml}$ milk. 
Determination of xanthine oxidase activity of goat's milk. This was determined as described for cow's milk, except that the milk was shaken for $20 \mathrm{~min}$ at room temperature before its activity was determined (Worden, I943). It was then adjusted to $\mathrm{pH} 8.8$ at $20^{\circ}$ with sodium hydroxide. The reaction mixture consisted of $\mathrm{I} \mathrm{ml}$ shaken milk $+2 \mathrm{ml} 0.25 \mathrm{M}$-glycylglycine/0.25 M-sodium phosphate buffer, $\mathrm{pH} 8.8$ at $20^{\circ}$ $\left(\mathrm{pH} 8.4\right.$ at $\left.37^{\circ}\right)$, tro $\mu$ moles xanthine $+\mathrm{I} \mathrm{mg}$ crystalline catalase $+100 \mu$ moles ethanol in a reaction volume of $3.4 \mathrm{ml}$ at a reaction temperature of $37^{\circ}$. The centre well contained $0.2 \mathrm{ml} 20 \%(\mathrm{w} / \mathrm{v})$ potassium hydroxide + filter paper.

The $\mathrm{pH}$ of 8.4 at $37^{\circ}$ and substrate concentration of $10 \mu$ moles per $3.4 \mathrm{ml}$ used for goat's milk differ appreciably from the $\mathrm{pH}$ and substrate concentration used to determine the xanthine oxidase activity of cow's milk as described above, so that activities determined with these two assay systems are not directly comparable. Xanthine oxidase is inhibited by its own substrate (Bray, 1959) so that the reaction rate is faster the greater the ratio of enzyme to substrate. Hence, the sensitivity of the reaction is increased by minimizing the substrate concentration. This was done for the determination of the activity of cow's milk in order to approach as closely as possible to the optimum xanthine concentration for the bovine milk enzyme of $0.1 \mathrm{~mm}$ (Bray, 1959). Activities determined at $\mathrm{pH} 8.4$ at $37^{\circ}$ and ro $\mu$ moles xanthine per $3.4 \mathrm{ml}$ may be made comparable with those determined at $\mathrm{pH} 8.8$ at $37^{\circ}$ and $4 \mu$ moles xanthine per $3.4 \mathrm{ml}$ by multiplying the former by $\mathrm{I} \cdot 27$, this factor being calculated from data on the variation of the activity of bovine milk xanthine oxidase with $\mathrm{pH}$ and with substrate concentration (Hart, 1964). All goat's milk xanthine oxidase activities determined under these suboptimal conditions and presented in this paper have been corrected in this way.

Determination of Mo in milk and feeding-stuffs. Cow's milk $(25 \mathrm{ml})$, goat's milk $\left(5^{\circ}-100 \mathrm{ml}\right)$ and feeding-stuffs $(\mathrm{r}-2 \mathrm{~g})$ were wet-washed by a modification of the nitric acid method of Middleton \& Stuckey (1954). Mo was determined in the residues with toluene-3,4-dithiol (Hart, 1964). All determinations were made in duplicate. Mo concentrations in milk were expressed as $\mu \mathrm{g} \mathrm{Mo} / \mathrm{roo} \mathrm{ml} \mathrm{milk.}$

Administration of sodium molybdate to cows maintained on a low-Mo diet. Six stallfed Ayrshire cows, all in early lactation, were divided into two groups (A and B) each containing three cows, so that the mean milk xanthine oxidase activity of the milk of group A was approximately equal to that of group B (determined over a period of I 4 days). The cows were offered a low-Mo diet consisting of hay and concentrates. The hay and the ingredients of the concentrates were all selected for their low Mo content, which was determined by the method described above. The composition of the concentrates was: bruised oats, 6 parts; bean meal, 5 parts; cooked maize, I part. Molasses ( $5 \%$ by weight) was added as a binder to this mixture which was compressed into pellets ('cubes') by a local supplier of animal feeding-stuffs.

Each cow was offered $3.6 \mathrm{~kg}$ hay and $3.6 \mathrm{~kg}$ concentrates twice daily. One cow in group A consistently refused to eat more than $5.4 \mathrm{~kg}$ concentrates daily. Otherwise, with rare exceptions, all the ration offered was consumed by every cow throughout the experimental period. The diet conformed to accepted standards for the protein intake of lactating cows (Wood \& Woodman, 1939). It was sufficient to provide for milk 
yields of some $16-181$./day while restricting the daily Mo intake of $5 \mathrm{mg} / \mathrm{cow}$ for the duration of the experiment $(4.5 \mathrm{mg}$ for the group A animal that, as mentioned above, did not eat the full amount of concentrates). This was the lowest daily Mo intake that could be achieved with the feeding-stuffs available.

On the roth day after the introduction of this basal diet the three cows of group A were each given a daily dose of $45 \mathrm{mg} \mathrm{Mo}$, thus raising their daily intake from 5 to $50 \mathrm{mg} \mathrm{Mo} / \mathrm{cow}$. The dose consisted of $57 \mathrm{ml}$ of a $0.20 \%(\mathrm{w} / \mathrm{v})$ aqueous solution of AR sodium molybdate, $\mathrm{Na}_{2} \mathrm{MoO}_{4} \cdot 2 \mathrm{H}_{2} \mathrm{O}$. It was administered by means of a standard cattle drenching gun at about I I.00 each day. This dosing was continued for a total period of Io days. Six days later the cows of group B were each given a daily dose of $95 \mathrm{mg} \mathrm{Mo}$, thus raising their daily intake from 5 to $100 \mathrm{mg} / \mathrm{cow}$. This dosing was continued for a total period of 10 days. The cows were kept on the basal diet for a further 7 days and the experiment then ended.

The duration of the experimental period, from the time that the cows were first offered the basal diet, was 43 days. Combined $24 \mathrm{~h}$ milk samples were taken every 2 nd day from each cow throughout this period. A $24 \mathrm{~h}$ milk sample was made by combining the milk from an afternoon milking (kept at $5^{\circ}$ overnight) with the following morning's milk, the combination being made in proportion to the respective yields. The daily milk yields from each cow on the day of sampling were recorded. The xanthine oxidase activities of the $24 \mathrm{~h}$ milk samples and the Mo contents of the milks were determined by the methods described above. For the first 7 days of the experimental period the xanthine oxidase activities of the milks were determined in $0.5 \mathrm{ml}$ milk in a reaction volume of $3.4 \mathrm{ml}$. For the remainder of the experimental period all the activities were determined in $0.25 \mathrm{ml}$ or $0.20 \mathrm{ml}$ milk in a reaction volume of $3.4 \mathrm{ml}$. Throughout the experimental period all activities were determined at the same dilution on any one day. The fat contents of the milks were determined by the Gerber method. The Mo content of the basal diet was determined throughout the experimental period by taking daily samples of the hay and concentrates. Once each week these were combined into single samples of hay and of concentrates and the Mo and moisture contents of these samples were determined. These analyses showed that the Mo content of the basal diet did not vary appreciably throughout the experimental period.

Administration of sodium molybdate to goats maintained on a low-Mo diet. Six British Saanen goats, all near the end of lactation, were arbitrarily divided into two groups of three, groups A and B. Each goat was confined in a separate pen and was offered $\mathrm{I} \cdot 4 \mathrm{~kg}$ hay and $0.7 \mathrm{~kg}$ concentrates twice daily. The composition of the concentrates was: bruised oats, 6 parts; bean meal, 4 parts; decorticated groundnut meal, I part; flaked maize, I part. This mixture was made up by a local supplier of animal feeding-stuffs. The daily Mo intake provided by the complete diet was $\mathrm{I} \cdot \mathrm{I} \mathrm{mg} /$ goat.

The goats were given this basal diet for ro days. At this point one goat in group B ceased to lactate and was replaced by another. All the results from the animal in which lactation stopped were discarded, so for the first ro days of the experimental period group B comprised two goats only. For the next 7 days the goats of group A were each given a daily dose of $\mathrm{I} I \cdot 9 \mathrm{mg}$ Mo, thus raising their daily intake from $\mathrm{I} \cdot \mathrm{I} \mathrm{mg}$ to $\mathrm{I} 3.0$ $\mathrm{mg} /$ goat. The dose was given as $30 \mathrm{ml}$ of a $0.10 \%(\mathrm{w} / \mathrm{v})$ aqueous solution of AR 
sodium molybdate. It was administered with a standard sheep drenching gun at about I 1 .oo each day.

After 7 days the dosing of group A was stopped, and on the following day the goats of group B were each given a similar daily dose, which was continued for a period of 7 days. The goats were kept on the basal diet for a further 3 days. The experiment then had to be terminated, since some of the goats were approaching the end of lactation.

Each goat was milked twice daily during the experimental period. The afternoon milk from each goat was stored at $5^{\circ}$ overnight and was combined with the milk obtained the following morning; the volumes of the combined yields were recorded. Samples for analysis were taken from these combined yields every Monday, Wednesday and Friday morning. The xanthine oxidase activities and Mo content of these samples were determined immediately by the methods described above.

Weekly samples of the hay and meal were taken and their Mo and moisture contents were determined. These analyses showed that the Mo content of the diet did not vary appreciably throughout the experimental period.

\section{RESULTS}

Effect of administration of sodium molybdate to cows maintained on a low-Mo diet. The results of this experiment are shown in Figs. $1-3$. Fig. I shows that the administration of sodium molybdate to either group of cows was followed immediately by a rise in the mean concentration of Mo in the milk of the dosed group, and that this concentration fell rapidly when dosing ceased. In the first 7 days of the experiment, when each cow was receiving $5 \mathrm{mg} \mathrm{Mo} / \mathrm{day}$, the mean content of Mo in the milk of all six cows over this period was $2.5 \mu \mathrm{g} \mathrm{Mo} / 100 \mathrm{ml}$ and the mean milk yield was approx. I7 l. This corresponds to a mean daily output of milk Mo per cow of $0.43 \mathrm{mg}$, i.e. about $9 \%$ of the daily intake. The highest outputs of Mo in the milk occurred during dosing with molybdate and represented $\mathrm{I} \cdot 4 \%$ of the daily intake of $50 \mathrm{mg} \mathrm{Mo} / \mathrm{cow}$ for group $\mathrm{A}$, and $\mathrm{I} \%$ of the daily intake of $100 \mathrm{mg} \mathrm{Mo} /$ cow for group B (Fig. $\mathrm{r}$ ).

Fig. I shows that, although oral Mo caused a marked rise in the concentration of Mo in the milk, little change occurred in the mean xanthine oxidase activity. Fig. 2 shows that the mean ratios of xanthine oxidase activity to Mo in the milks of the two groups were initially similar, that they diverged sharply as soon as dosing of one group with sodium molybdate was begun, and that they converged rapidly after dosing ceased. Fig. 2 also shows that, with the exception of the first 7 days of the experiment (see p. 626), the ratios of activity to Mo in the milks of the control groups remained fairly constant. Fig. 3 shows that no marked changes occurred either in the mean fat contents of the milk or in the mean milk yields of either group throughout the experiment.

Xanthine oxidase activities, Mo contents, and activity to Mo ratios of milk samples taken before Mo dosing was begun are given in Table 1 .

Throughout this experiment the cows remained healthy, and at no time were there any signs of molybdenosis (cf. Underwood, I962).

Effect of administration of sodium molybdate to goats maintained on a low-Mo diet. 

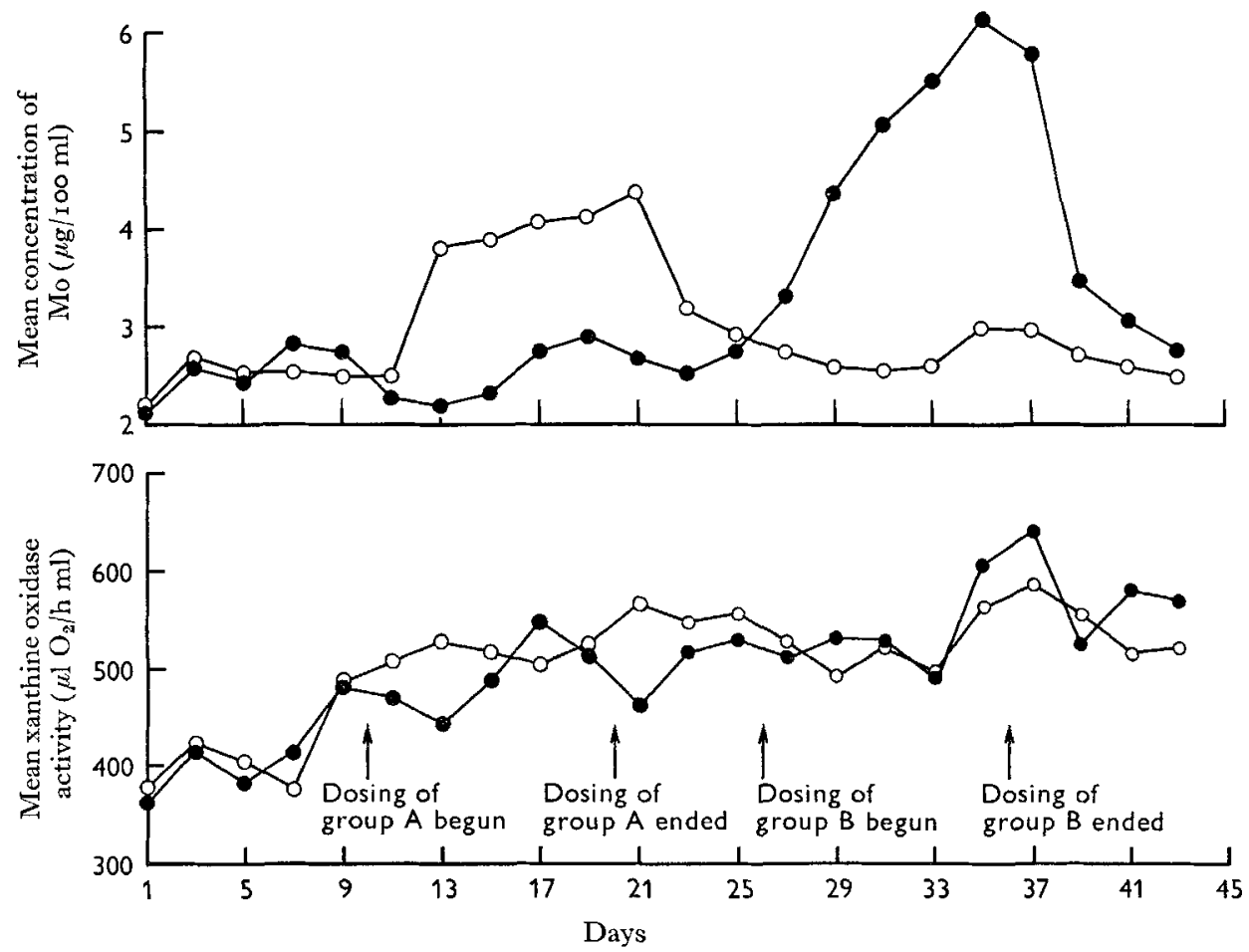

Fig. I. Mean xanthine oxidase activities and molybdenum concentrations of the milk of two groups of cows before and after dosing with sodium molybdate. $\mathrm{O}-\mathrm{O}$, group $\mathrm{A} ; \mathbf{0}-\mathbf{0}$, group B.

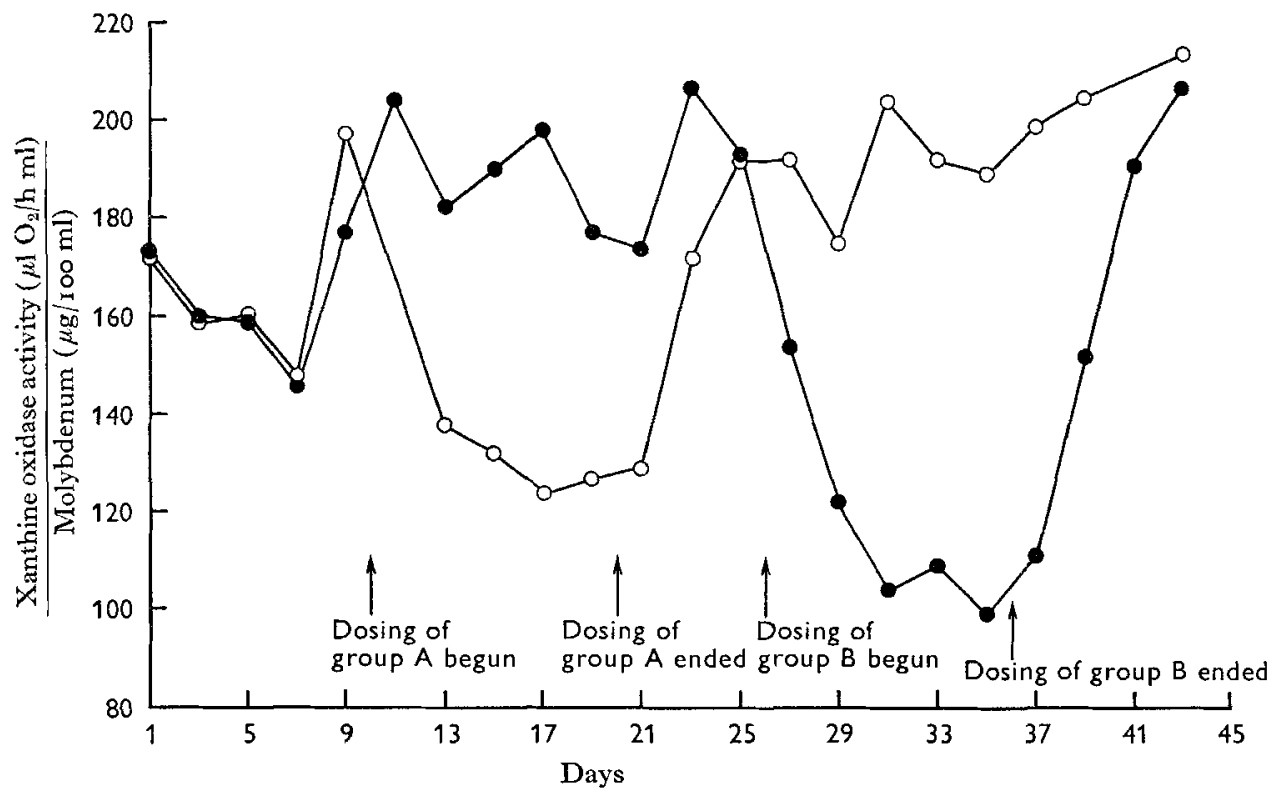

Fig. 2. Mean ratios of xanthine oxidase to molybdenum in the milk of two groups of cows before and after dosing with sodium molybdate. $\mathrm{O}-\mathrm{O}$, group $\mathrm{A}$; -0 , group $\mathrm{B}$. 

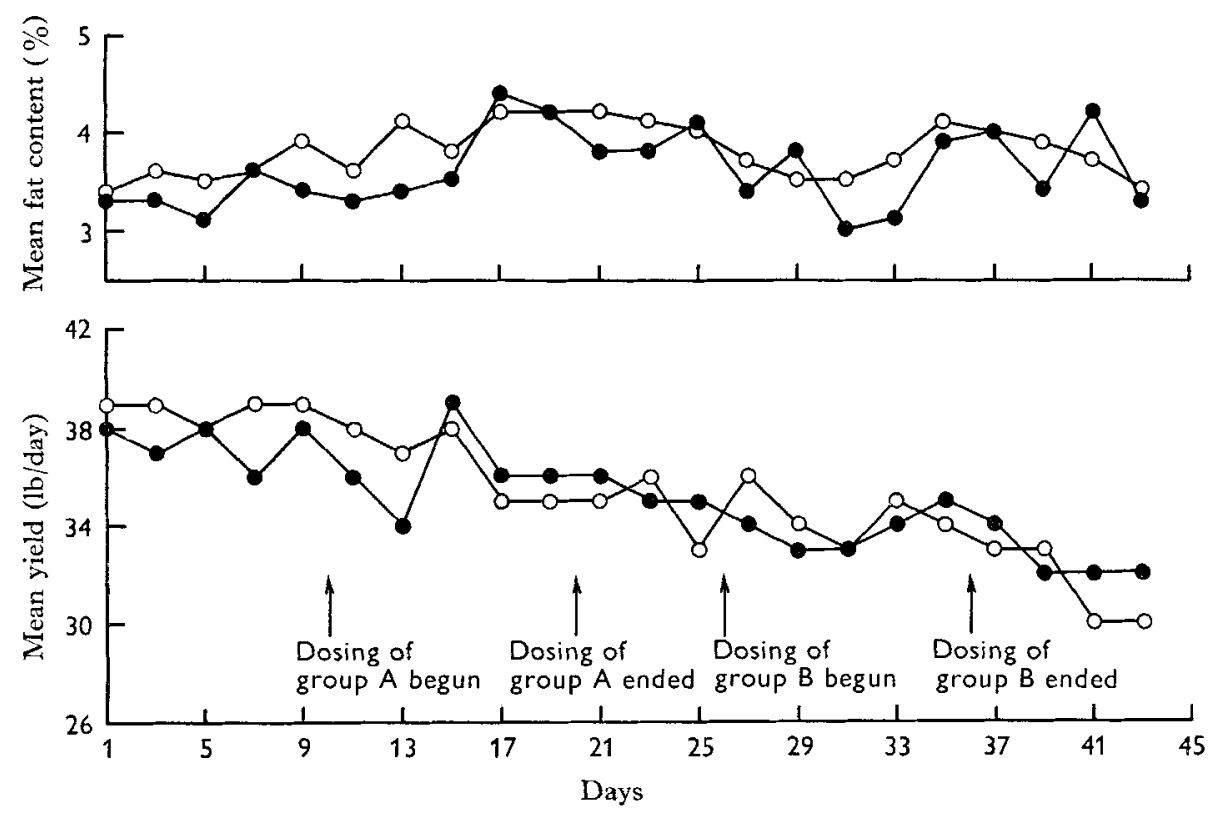

Fig. 3. Mean yields and fat contents of the milk of two groups of cows before and after dosing with sodium molybdate. $\mathrm{O}-\mathrm{O}$, group $\mathrm{A}$; - group $\mathrm{B}$.
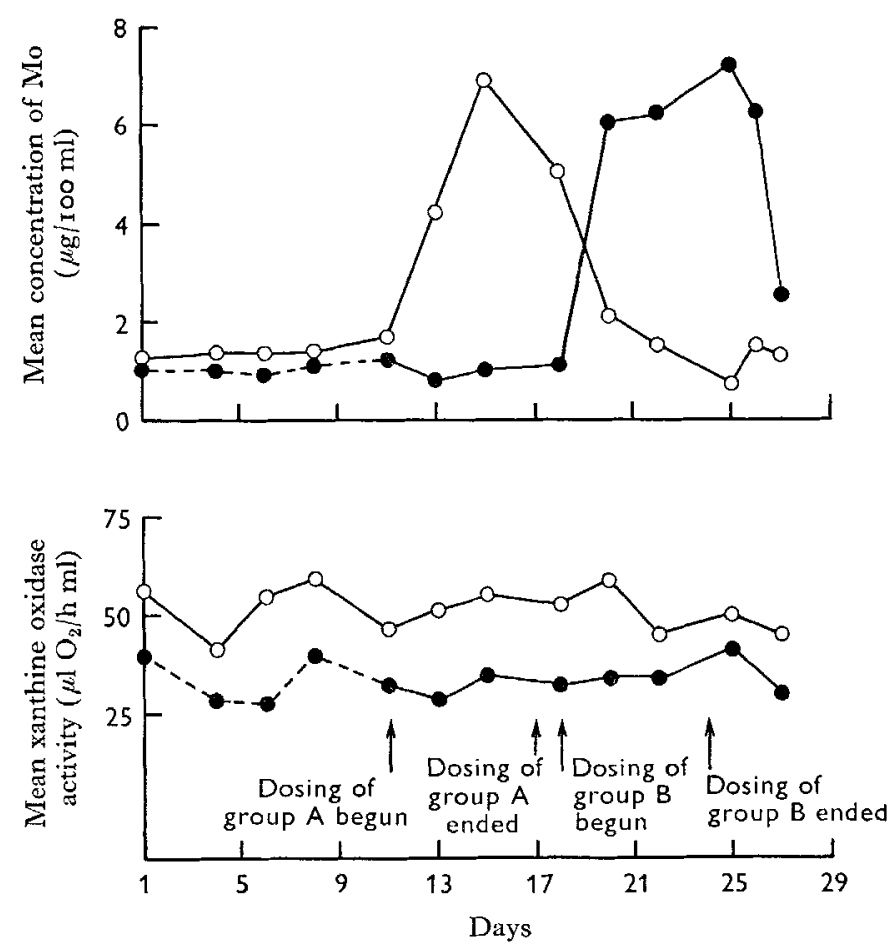

Fig. 4. Mean xanthine oxidase activities and molybdenum contents of the milks of two groups of goats before and after dosing with sodium molybdate. $O$, group $A ; \boldsymbol{\theta}$, group $B$. 

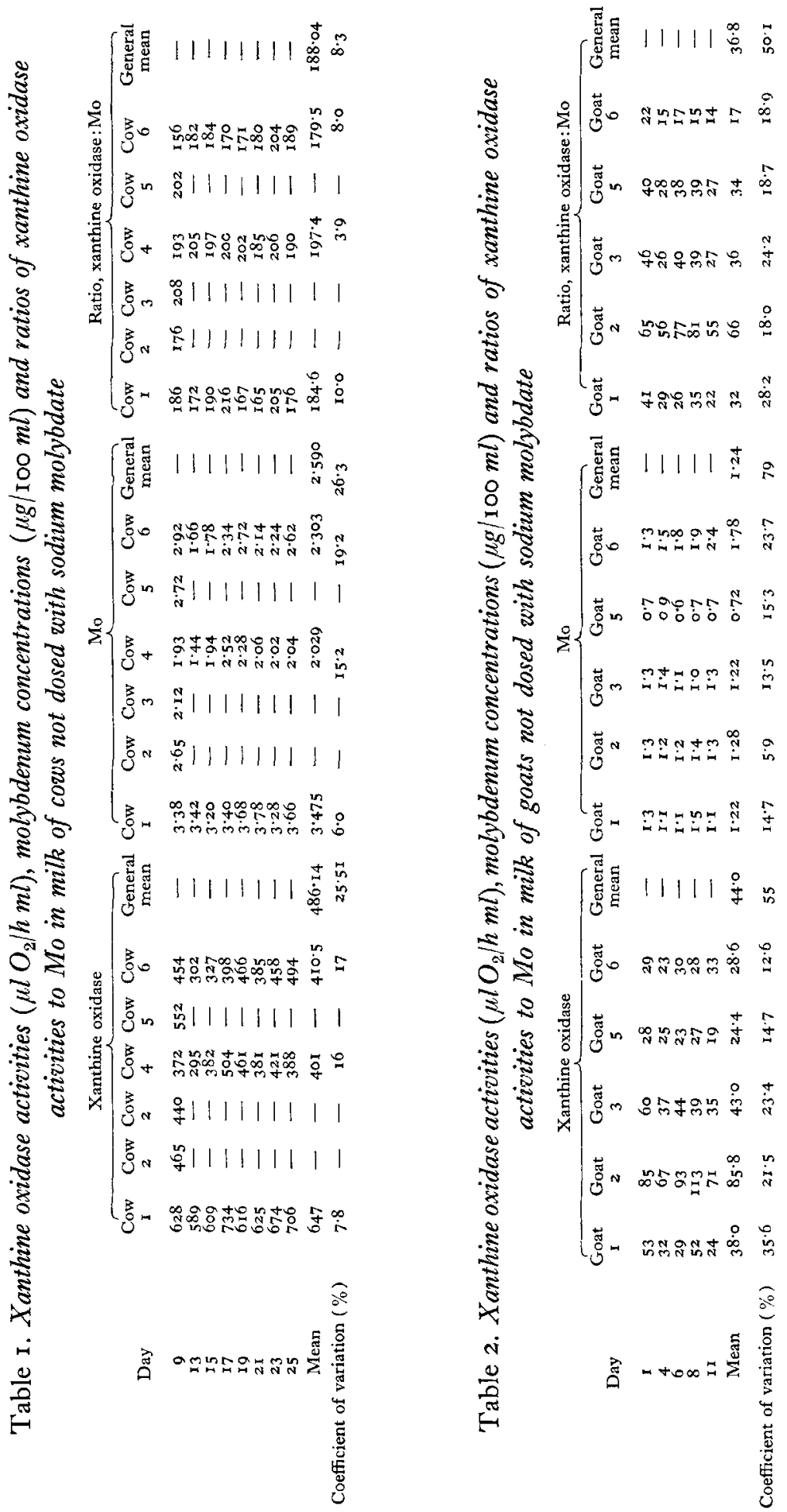
Vol. 2I

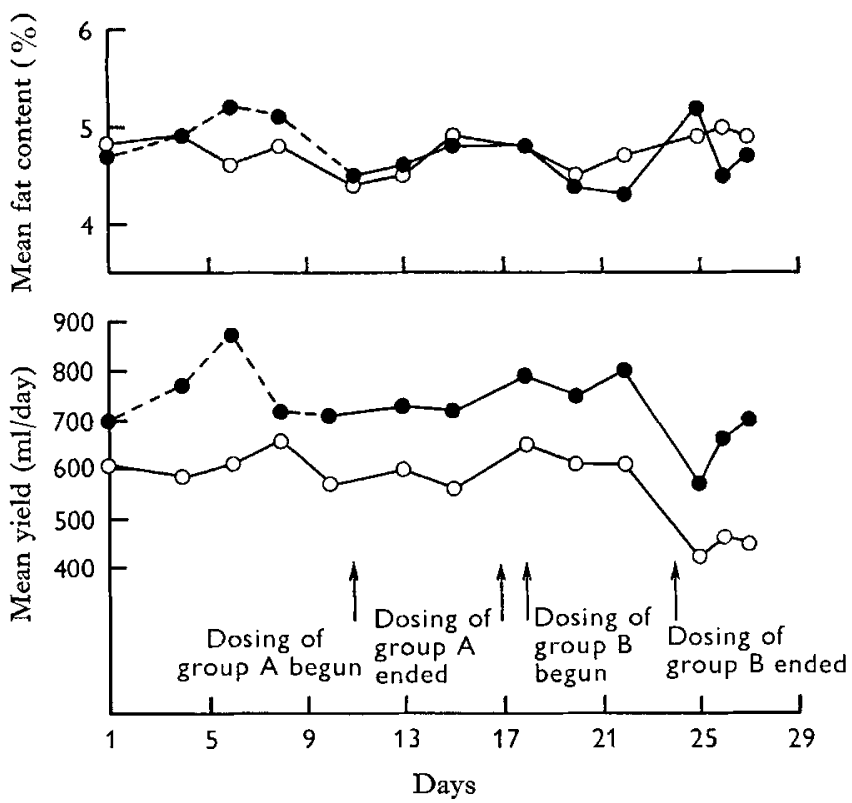

Fig. 5. Mean yields and fat contents of the milks of two groups of goats before and after dosing with sodium molybdate. $O$, group $A ; 0$, group $B$.

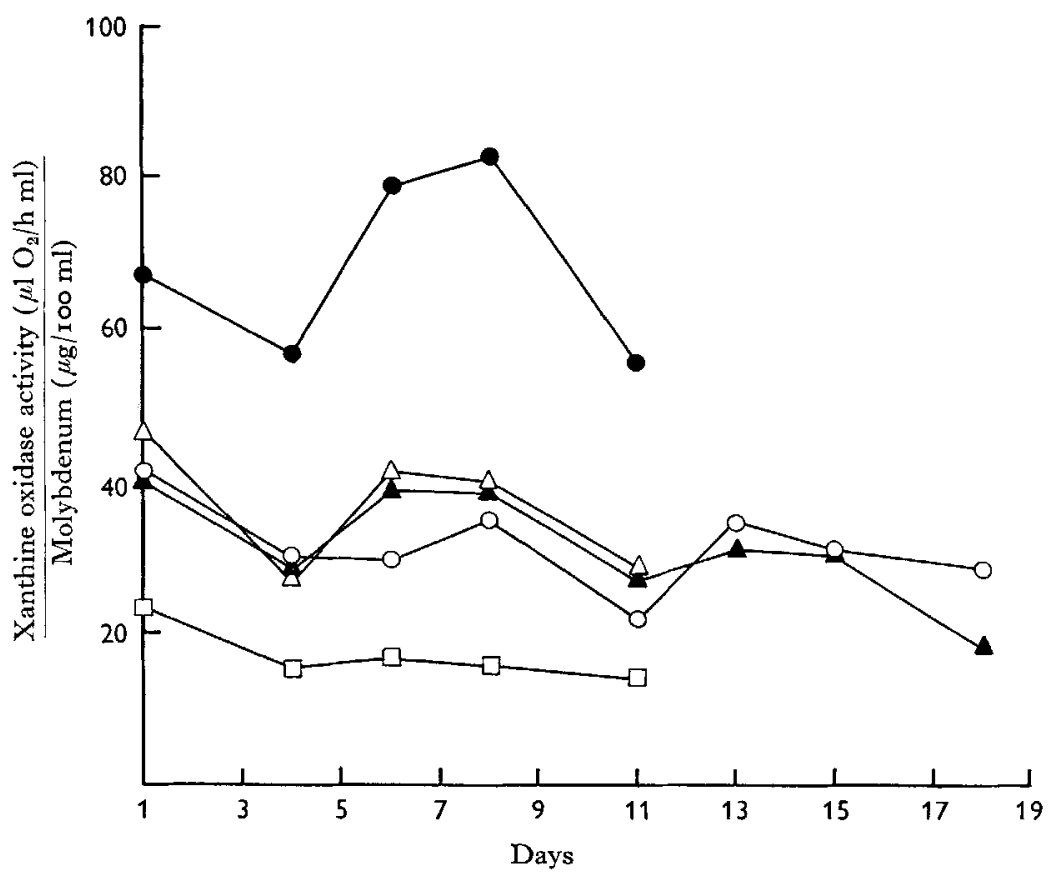

Fig. 6. Natural variations of the ratio of xanthine oxidase to molybdenum in the milk of goats before the administration of sodium molybdate. 0 , goat no. 1 ; $\odot$, goat no. $2 ; \triangle$, goat no. 3 ; $\Lambda$, goat no. $5 ; \square$, goat no. 6 . 
The results of this experiment are shown in Figs. $4^{-6}$. As in the preceding experiment administration of sodium molybdate was followed immediately by a rise in the mean Mo content of the milks but the xanthine oxidase activities remained unchanged (Fig. 4). However, these activities were very low compared with the activity of cow's milk (compare Figs. I and 4) and in some instances they were barely detectable by the manometric method.

Fig. 5 shows that, as in the experiment with cows, no marked changes occurred in either fat content or yield of milk during the experimental period.

Xanthine oxidase activities, Mo contents, and ratios of activity to Mo of milk samples taken before Mo dosing began are shown in Table 2. Fig. 6 shows the variation with time of the ratios of activity to Mo content of the milks of individual goats, taken before Mo dosing began.

\section{DISCUSSION}

\section{Cows}

Table I shows that a nearly constant value for the ratio of xanthine oxidase activity to Mo is found in the milks of cows not dosed with sodium molybdate, in agreement with the finding of Kiermeier \& Capellari (1958). This constancy probably implies that, in such milk, all the Mo is bound to enzymically active xanthine oxidase. However, much higher, but variable values of this ratio have been found in purified xanthine oxidase isolated from cow's milk. Some preparations were as much as $67 \%$ more active than the mean value shown in Table I (Hart, unpublished). The value found in such preparations is dependent on the method used to isolate the enzyme from cow's milk (Hart, unpublished). Possibly the method used to release the xanthine oxidase from the enzymically inactive form occurring in fresh raw milk (Wieland \& Macrae, r930; Worden, 1943; Robert \& Polonovski, 1955) was releasing a constant proportion of this activity. The possibility that a constant proportion of the total activity of the milk was being inhibited by some constituent of the milk was eliminated by determining the activity at various milk dilutions. Some inhibition of activity at a dilution of $0.5 \mathrm{ml}$ milk in $3.4 \mathrm{ml}$ reaction mixture was indeed found in milks from the cows used in this work, but this was negligible at the milk dilutions employed for the determination of activity after the first 7 days $(0.20$ or $0.25 \mathrm{ml}$ milk in $3.4 \mathrm{ml}$ reaction mixture). This is the reason for the apparent sudden increase in activity of the milk of groups $A$ and $B$ after the 7 th day, when the amount of milk taken for the determination of activity was changed from $0.5 \mathrm{ml}$ to $0.25 \mathrm{ml}$ or $0.20 \mathrm{ml}$ in $3.4 \mathrm{ml}$ reaction mixture.

The finding that the administration of a soluble molybdate to cows is followed by a rapid increase in the concentration of Mo in their milk without any accompanying change in xanthine oxidase (Fig. I) is in agreement with the findings of Kiermeier \& Capellari (1958). The mean ratio of xanthine oxidase activity to Mo in the milk of the cows during the days when no molybdate was being given varied around a constant value (excluding the values from the first 7 days of the experiment). However, the mean ratio during dosing fell sharply and remained low while dosing continued, but returned rapidly to the former constant value when dosing ceased. 
It can be shown by graphing the results in Table I that, in the cow's milk, xanthine oxidase was a linear function of the Mo concentration; the correlation coefficient, calculated from all the figures in Table 1 , was

$$
r_{X o \times \mathrm{Mo}}=+0.9386(P<0.00 \mathrm{r}),
$$

and the straight line fitted by the method of least squares through the average of all the figures was

$$
X O=170 \cdot 74 \mathrm{Mo}+43 \cdot 86 .
$$

Kiermeier \& Capellari (1958) compared cows grazing on pastures which differed in Mo content by a factor of 27. The xanthine oxidase activity of the milk of the herd grazing on the Mo-rich pasture was about three times that of the other herd. Because this difference of activity could not with any certainty be attributed to the differences in Mo contents of the pastures, Kiermeier \& Capellari next compared the xanthine oxidase activities of the milks of a single group of cows initially fed on a Mo-poor, protein-poor diet of hay, and subsequently on a protein-rich diet of hay plus concentrates. On the former diet the mean xanthine oxidase activity of the milk fell slightly, but it increased about $\mathrm{I} \cdot 8$-fold on changing to the latter diet.

This rise was attributed to the increase in the Mo content of the diet, but could equally well have been due to the increase in the protein content of the diet, since Litwack, Williams, Feigelson \& Elvehjem (1950), Litwack, Williams, Chen \& Elvehjem (1952) and Litwack, Williams, Fatterpaker, Chen \& Elvehjem (1953) have shown that the xanthine oxidase of rat liver is markedly dependent both on the amount, and on the lysine content, of the dietary protein. Elvehjem and his colleagues also found that riboflavine is required by the rat for maximal hepatic xanthine oxidase.

In a further experiment Kiermeier \& Capellari (1958) fed two cows on a diet of hay and turnips that provided a daily intake of about $2.6 \mathrm{mg} \mathrm{Mo} / \mathrm{cow}$, and found that after 15 days the Mo level in the milk of these cows fell to a mean value of about $\mathrm{I} \cdot 5 \mu \mathrm{g} \mathrm{Mo} / \mathrm{I} 00 \mathrm{ml}$ milk. When they then changed the diet to hay, from a different source, with turnips, so that the daily intake was about $34 \mathrm{mg} \mathrm{Mo} / \mathrm{cow}$, they observed 2- to 3 -fold increases in both the xanthine oxidase and Mo of the milks. However, because two different diets were employed, this experiment is open to the objection that the two feeding periods were not strictly comparable, for an undiscovered factor might have been operating.

As regards the differences between the cow and the goat, xanthine oxidase in milk was shown by Modi, Owen \& Proudfoot (1959) to vary widely from one species of mammal to another for they found it in maximal amounts in cow's milk and in lesser amounts in the milk of the goat, ewe and rabbit. They could not find it at all in the milk of the mare, sow and woman. Later, using a more sensitive modification of a colorimetric method, Owen, Hart \& Hytten (1962) did find traces of the enzyme in human milk. Owen \& Proudfoot (unpublished) mixed molybdate intimately with a variety of cattle diets in which the level of sulphate was varied by known amounts. Sulphate and molybdate in these experiments caused scouring only when simultaneously fed, but changes of xanthine oxidase in the milk of the cows could not, with any certainty, be attributed to any particular change of diet. Crossland, Owen \& Proudfoot (1958) 
found no change in xanthine oxidase in the milk of goats which were almost entirely dependent on microbial synthesis for lysine, tryptophan and riboflavine, each of which is known to increase xanthine oxidase in the liver of the rat. Clearly many factors may affect xanthine oxidase levels in milk.

In the present work each cow of group B was eating each day, as a natural constituent of its diet, $5 \mathrm{mg}$ Mo for 25 days, and the Mo content of the milk fluctuated about a mean of $2.5 \mu \mathrm{g} / \mathrm{roo} \mathrm{ml}$ (Fig. I), which is of the same order of magnitude as Kiermeier \& Capellari's ( $\left.195^{8}\right)$ lowest value of ${ }_{1} \cdot 5 \mu \mathrm{g} \mathrm{Mo} / \mathrm{r} 00 \mathrm{ml}$ milk. However, when the Mo intake of the cows of group B was increased to $100 \mathrm{mg} / \mathrm{cow}$, without any other change of the diet, the xanthine oxidase of the milk showed only a slight increase (Fig. I), and Fig. 3 shows that this was not related to the Mo content of the milk.

\section{Goats}

The finding that the administration of sodium molybdate to goats is followed immediately by a rise in the Mo content of their milk but that the xanthine oxidase activity of the milk is unaffected, parallels the results obtained with the cows. The finding that the xanthine oxidase activities of the milk of goats were much lower than those of cow's milk is in agreement with the observations of Morgan et al. (1922) and of Modi et al. (1959). Likewise, the finding that Mo contents of goat's milk are slightly lower than those of cow's milk is in agreement with the findings of Teresi et al. (1942). The low and variable ratios of xanthine oxidase activity to Mo in the milks of undosed goats (Table 2) are, however, in marked contrast to the much higher and more constant value of the ratio found for cow's milk (Table 1 ).

The possibility that these low and variable ratios might be because the goats were nearly at the end of lactation was eliminated by determining the value of the ratio in the milk of goats at mid-lactation, when values similar to those in Table 2 were found. The possibility that the low activity of goat's milk could have been due to the presence of an inhibitor of xanthine oxidase was tested by determining the activities of samples of cow's and of goat's milks and of a I: I mixture of these milks. The activity of the mixture was found to be equal to the sum of the respective activities (Hart, 1964). A third possibility was that xanthine oxidase may have been present in goat's milk in a very tightly bound and therefore inactive form, analogous to that found in fresh cow's milk, and not released by the shaking treatment. Fig. 6 shows that, over a period of time, values for the ratio of activity to Mo of the milk of individual goats varied around a value characteristic of the particular animal, possibly suggesting that the enzyme is more tightly bound in some milks than in others. This hypothesis was tested by subjecting goat's milk to longer shaking periods of up to $2 \mathrm{~h}$ followed by incubation for $\mathrm{r} h$ at room temperature with $0.008 \mathrm{M}-\mathrm{L}-\mathrm{cysteine}$ hydrochloride, a treatment that increased the xanthine oxidase of cow's milk shaken for only i h by $24 \%$ (Hart, I964), but no increase in the ratio of activity to Mo resulted from treating goat's milk in this way.

Comparison of Tables I and 2 shows that the overall coefficients of variation of xanthine oxidase activity and of the Mo concentration were considerably bigger for 
the goats than for the cows but this can be attributed only partly to the fact that the amounts of enzyme and Mo which had to be determined were much smaller in the milks of the goats than in the milks of the cows. The smallest xanthine oxidase value for the cows in Table I (295 units) was much larger than the largest for the goats (I I 3 units; Table 2). The coefficient of variation for the ratio of xanthine oxidase activity to Mo for all the goats was $50 \cdot 1 \%$. By contrast, that for all the cows was only $8.3 \%$. The large average ratio of xanthine oxidase activity to Mo (188.0, Table I) for the cows as compared with only $36 \cdot 8$ for the goats (Table 2) may have yet another explanation for there could be a natural excess of molybdate over the enzyme in goat's milk. This hypothesis is supported by the great variation from goat to goat in Mo concentration (coefficient of variation $=79 \%$ ). Goat no. 6 had very little less Mo in its milk than cows no. 3,4 or 6 while at the same time its average xanthine oxidase activity was only 28.6 (Table 2). Since both cow and goat have been shown by the present experiments to be able to secrete dietary molybdate into their milk with no accompanying change in xanthine oxidase, the Mo concentrations (Table 2) in goat's milk are consistent with the hypothesis that goat's milk normally contains Mo in excess of that required to form xanthine oxidase. Both goats and cows were on similar diets in the present experiments so that the goats would have had more than enough Mo for their low-activity milk. In the goats the largest ratio of xanthine oxidase activity to Mo (66 for goat no. 2) was four times the smallest ( 6 for goat no. 6) so that the correlation, between these two variables, which was found for the cows did not apply to the goats. From the values for the goats, in Table 2, it can be calculated that:

$$
r_{X O} \times M_{0}=+0.1502,
$$

which is without statistical significance (Fisher \& Yates, 1938).

Whether the goats naturally have Mo in their milk in excess of xanthine oxidase or whether the Mo is bound to inactive xanthine oxidase cannot be judged from the present experiments; dialysis might reveal excess Mo, for it is known that Mo is firmly bound to the enzyme (Bergel \& Bray, 1958) which cannot be reactivated once its Mo has been separated from it.

\section{REFERENCES}

Andrews, P., Bray, R. C., Edwards, P. \& Shooter, K. V. (1964). Biochem. F. 93, 627.

Avis, P. G., Bergel, F. \& Bray, R. C. (1956). F. chem. Soc. p. 1219.

Bergel, F. \& Bray, R. C. (1958). Symp. Biochem. Soc. 15, 64.

Bray, R. C. (1959). Biochem. F. 73, 690.

Bray, R. C., Pettersson, R. \& Ehrenberg, A. (r96r). Biochem. F. 81, r 78.

Crossland, A., Owen, E. C. \& Proudfoot, R. (1958). Br. F. Nutr. 12, 3 I 2.

De Renzo, E. C., Kaleita, E., Heytler, P. G., Oleson, J. J., Hutchings, B. L. \& Williams, J. H. (I953). Archs Biochem. Biophys. 45, 247.

Fisher, R. A. \& Yates, F. (1938). Statistical Tables for Biological, Agricultural and Medical Research. London: Oliver and Boyd.

Green, D. E. \& Beinert, H. (1953). Biochim. biophys. Acta II, 599.

Hart, L. I. (1964). Some aspects of riboflavin metabolism in the ruminant. $\mathrm{PhD}$ Thesis, University of Glasgow.

Keilin, D. \& Hartree, E. F. (1945). Biochem. F. 39, 293.

Kiermeier, F. \& Capellari, K. (1958). Biochem. Z. 330, 160.

Litwack, G., Williams, J. N. Jr., Chen, L. \& Elvehjem, C. A. (1952). F. Nutr. 47, 299.

Litwack, G., Williams, J. N. Jr., Fatterpaker, P., Chen, L. \& Elvehje m, C. A. (1953). F. Nutr. 49, 579.

Litwack, G., Williams, J. N. Jr., Feigelson, P. \& Elvehjem, C. A. (1950). F. biol. Chem. 187, 605. 
Middleton, G. \& Stuckey, R. E. (1954). Analyst, Lond. 79, I 38 .

Modi, V. V., Owen, E. C. \& Proudfoot, R. (1959). Proc. Nutr. Soc. 18, i.

Morgan, E. J., Stewart, C. P. \& Hopkins, F. G. (1922). Proc. R. Soc. B, 94, 109.

Owen, E. C., Hart, L. I. \& Hytten, F. E. (1962). Proc. Nutr. Soc. 21, xv.

Richert, D. A. \& Westerfeld, W. W. (1953). F. biol. Chem. 203, 915.

Robert, L. \& Polonovski, J. (1955). Disc. Faraday Soc. 20, 54.

Teresi, J. D., Elvehjem, C. A. \& Hart, E. B. (1942). Am. F. Physiol. 137, 504.

ter Meulen, H. (1932). Nature, Lond. r30, 966.

Totter, J. R., Burnett, W. T. Jr., Monroe, R. A., Whitney, I. B. \& Comar, C. L. (1953). Science, N.Y. Ir8, 555 .

Underwood, E. J. (1962). Trace Elements in Human and Animal Nutrition, and ed., p. Iog. New York and London: Academic Press Inc.

Wieland, H. \& Macrae, T. F. (r930). Liebigs Ann. 483, 217.

Wood, T. B. \& Woodman, H. E. (1939). Bull. Minist. Agric. Fish. Fd, Lond. no, 48, roth ed.

Worden, A. N. (1943). Nature, Lond. 152, 505. 